\section{CONTRIBUIÇĀO AO ESTUDO DA ANATOMIA PATOLÓGICA E DA PATOGÊNESE DO MEGAESÔFAGO CHAGÁSICO}

Foram analisadas e comparadas as alteraçōes morfológicas das diversas camadas de 56 esôfagos de chagásícos crônicos ( 17 com e 39 sem mega) e de 26 não chagásicos. Com base nos achados morfométricos obtidos e em dados obtidos e em dados da literatura, considerou-se como megaesôfago (ME) os casos, cujo diâmetro do órgão ultrapassou $2,5 \mathrm{~cm}$, na ausência de qualquer obstáculo mecânico.

Macroscopicamente, a parede do órgão apresentou-se espessada em treze casos $(76,5 \%)$, normal em três $(17,7 \%)$ e diminuida em um $(5,8 \%)$. O aumento de espessura da parede da víscera, acompanhado de dilatação, indica o caráter permanente da lesão.

Microscopicamente, $o$ anel esofágico retirado, do terço inferior, mostrou que, nos chagásicos, as lesões mais intensas localizam-se na muscular própria e nos gânglios do plexo de Auerbach. Na muscular, confirmando dados da literatura, havia focos de miosite, ora isolados, ora múltiplos, por vezes confluentes, acompanhados de degeneração e/ou necrose das fibras musculares lisas. Nos megas, focos de miosite foram observados em $94,1 \%$ dos casos e nos chagásicos sem ME, em $64,2 \%$; também foram vistos em $15,4 \%$ dos esôfagos controles, semelhantes qualitativamente aos precedentes e cujo significado é obscuro. Fibrose da muscular, associada ou nào aos focos de miosite, esteve presente não somente em $94,1 \%$ dos megas e em $41,0 \%$ dos esôfagos de chagásicos sem mega, mas também em $19,2 \%$ dos esôfagos de não chagásicos. De modo semelhante à miosite, a fibrose era mais intensa e extensa nos megaesôfagos. $\mathrm{Na}$ muscular foi detecado maior número de mastócitos nos megas, em relação aos esôfagos não dilatados e aos controles. A análise conjunta das alteraçōes da muscular mostra que, qualitativamente, as lesões são superponiveis às observadas no miocádio dos chagásicos crônicos, sugerindo, assim, que a patogenese e o potencial evolutivo destes processos possam ser comuns.

A pesquisa sistematizada de $T$. cruzi, através da técnica de peroxidase-antiperoxidase (PAP), feita em cinco lâminas de cada anel de oito esôfagos com mega e oito de chagásicos sem ME, mostrou-se positiva em quatro casos, todos com ME.

Os gânglios do plexo de Auerbach mostraram, tanto nos chagásicos como nos controles, infiltrado predominantemente mononuclear. Esta ganglionite foi

\section{CONTRIBUTION TO THE STUDY OF THE PATHOLOGY AND PATHOGENESIS OF THE CHAGASIC MEGAESOPHAGUS}

Morphologic alterations in the esophagus of several layers of 56 chronic chagasics ( 17 with and 39 without megas) were compared with the ones in 26 nonchagasic esophagi. Morphometric data from the literature and our own, indicate that megaesophagus occurs when the esophageal diameter without mechanical obstacle is larger than $2.5 \mathrm{~cm}$.

Gross exam showed the esophageal wall to be thickened in thirteen cases $(76.5 \%$ ), normal in three $(17.7 \%)$ and thinned in one $(5.8 \%)$. The dilatation associated with increased wall thickness indicated that the former lesion is permanent.

Microscopically, an esophagic ring removed from the lower third showed that in chagasics, the more intense lesions are found in the muscularis propria and in the plexus of Auerbach ganglia. As previosly shown in the literature, there were foci of myositis in the muscularis propria either isolated or multiple, sometimes confluent, followed by degeneration and/or necrosis of smooth muscle fibers. Myositic foci were found in $94.1 \%$ of the megas and in $64.2 \%$ of chagasics without megas. For unknown reasons similar foci were also seen in $15.4 \%$ of control esophagi. Muscular fibrosis, associated or not with myositic foci, was shown in $94.1 \%$ megas, in $41.0 \%$ chagasic esphagi without megas, and in $19.2 \%$ nonchagasic esophagi. Fibrosis, as myositis, was severe and extensive in megaesophagus. The highest count of mast cells in the muscularis propria was found in megas when compared with non-dilated chagasic esophagi and control ones. The simultaneous analysis of muscular alterations shows that qualitatively, the lesions are the same as those observed in the myocardium of chronic chagasics. This suggests that the pathogenesis and natural history of these processes can ben common.

A systematic search for $T$. cruzi using the peroxidase-antiperoxidase technique (PAP) in five slides of each ring was found positive in four out of eight esophagi with mega and in none of eight chagasic esophagi without mega.

The Auerbach plexus ganglia showed round cell infiltration in both chagasics and controls. This ganglionitis was more severe in dilated esophagus. The consequence of the round cell infiltration in the ganglia and myositis was unclear because it was not associated with neuronal depopulation. Similar findings are des- 
Resumo de Tese. Adad SJ. Contribuição ao estudo da anatomia patológica e da patogênese do megaesôfago chagásico. Revista da Sociedade Brasileira de Medicina Tropical 23: 63-64, jan-mar, 1990.

mais intensa nos esôfagos dilatados. Nos controles, a exemplo do que ocorreu com a miosite, o infiltrado dos gânglios teve significado obscuro, visto que não estava associado à despopulação neuronal. Fato semelhante pode ser visto nos gânglios do sistema nervoso intracardíaco. $\mathrm{O}$ estudo quantitativo, do plexo mientérico, mostrou maior despopulação neuronal nos esôfagos com mega, em relação aos sem $\mathrm{ME}$ e destes em relação aos controles. Embora o presente estudo confirme a regra de que nāo há $\mathrm{ME}$ sem denervação acentuada, nâo foi possivel determinar qual o percentual de destruição necessário para que ocorra a dilatação do esôfago. Por outro lado, esôfagos com intensa denervação podem apresentar calibre normal. É possível que, do mesmo modo que na cardiopatia chagásica crônica, sejam múltiplos os fatores que desencadeiam a esofagopatia, especialmente o ME.

As alterações das demais camadas do esôfago, como acantose, ceratizinação e ulceração da mucosa e inflamação e fibrose da submucosa, são secundárias e não parecem participar da gênese do processo. cribed for intracardiac nervous system ganglia. Morphometry showed that the megaesophagial myenteric plexuses are more depopulated when compared with non-mega chagasic esophagi and even more when compared with the controls. This study confirms the rule that there is no megaesophagus without severe denervation. It was not possible to find out which was the least amount of destruction enough to cause esophageal dilatation. On the other hand, there are normal caliber esophagi with severe denervation. It is possible that, as found with chronic chagasic cardiopathy several factors may lead to established megaesophagus.

Alterations such as acanthosis, mucosal keratinization and ulceration, and submucosal inflammation and fibrosis are secondary and do not seem to be involved with the development of the process.

\author{
Sheila Jorge Adad \\ Tese apresentada a Faculdade de Medicina \\ do Triângulo Mineiro para \\ obtenção do Título de Mestre \\ Uberaba, Minas Gerais, Brasil, 1989
}

